\title{
NUTRIENT CYCLING IN EUCALYPTUS DUNNII: MICRONUTRIENTS IN THE LITTERFALL
}

\author{
Dione Richer momolli ${ }^{*}$, Mauro Valdir Schumacher ${ }^{2}$, Aline Aparecida Ludvichak ${ }^{1}$, Kristiana Fiorentin dos \\ Santos ${ }^{3}$ Huan Pablo de Souza ${ }^{1}$, Claudiney do Couto Guimarães ${ }^{1}$ \\ ${ }^{1}$ Federal University of Santa Maria, Postgraduate Program in Forest Engineering. Santa Maria, Rio Grande do Sul, Brasil - \\ dionemomolli@gmail.com*, aline_lud@yahoo.com.br, huan.pablo@hotmail.com, claudiney.couto@hotmail.com \\ ${ }^{2}$ Federal University of Santa Maria, Prof. Full. Department of Forest Sciences, Santa Maria, RS - Brasil. E-mail: \\ mvschumacher@gmail.com \\ ${ }^{3}$ Blumenau Regional University Foundation, Postgraduate Program in Forest Engineering. Blumenau, Santa Catarina, Brasil. \\ kristianafiorentil@gmail.com
}

Recebido para publicação: 05/12/2017 - Aceito para publicação: 18/02/2019

\begin{abstract}
Resumo
Ciclagem de nutrientes em Eucalyptus dunnii: micronutrientes na serapilheira produzida. A avaliação da produção de serapilheira e retorno de nutrientes é importante para a compreensão da dinâmica de ciclagem de nutrientes. Embora exigidos em quantidades inferiores pelas plantas, os micronutrientes possuem importância singular na regulação biogeoquímica. O objetivo do presente estudo foi quantificar a serapilheira produzida e a concentração de micronutrientes nas diferentes frações e estações do ano em um povoamento de Eucalyptus dunnii. Foram demarcadas 4 parcelas de $20 \mathrm{~m}$ x $21 \mathrm{~m}$. A coleta da serapilheira da fração folhas, galhos finos (diâmetro $<0,5 \mathrm{~cm}$ ) e miscelânea, deu-se pela instalação de 4 coletores com área de $0,5 \mathrm{~m}^{2} \mathrm{em}$ cada parcela. Para a quantificação da fração galhos grossos (diâmetro $>0,5 \mathrm{~cm}$ ), em cada parcela foram demarcadas 4 áreas úteis das árvores de diâmetro médio. A fração foliar representou $59 \%$ da serapilheira e a ordem de transferência foi $\mathrm{Mn}>\mathrm{Fe}>\mathrm{B}>\mathrm{Zn}>\mathrm{Cu}$, totalizando 8,04 $\mathrm{kg} \mathrm{ha}^{-1}$. A fração foliar apresentou as maiores concentrações para B e Mn. A produção de serapilheira mostrou-se estacional com verão e primavera diferindo estatisticamente do inverno e a variável temperatura explica o padrão de deposição da mesma.

Palavras-chave: fertilização; sustentabilidade; nutrição florestal.
\end{abstract}

\begin{abstract}
The evaluation of litterfall and nutrient return is important for understanding the dynamics of nutrient cycling. Although required in smaller quantities by plants, micronutrients have unique importance in biogeochemical regulation. The objective of the present study was to quantify the litterfall and the concentration of micronutrients in the different fractions and seasons of the year in Eucalyptus dunnii stand. Four plots of 20 $\mathrm{m} \times 21 \mathrm{~m}$ were demarcated. The collection of leaf litter, twigs (diameter $<0.5 \mathrm{~cm}$ ) and miscellaneous resulted in the installation of 4 collectors with an area of $0.5 \mathrm{~m}^{2}$ in each plot. For the quantification of the thick branches fraction (diameter $>0.5 \mathrm{~cm}$ ), four useful areas of medium-diameter trees were demarcated in each plot. The leaf fraction represented 59\% of litterfall and the transfer order was $\mathrm{Mn}>\mathrm{Fe}>\mathrm{B}>\mathrm{Zn}>\mathrm{Cu}$, totaling $8.04 \mathrm{~kg} \mathrm{ha}^{-1}$. The leaf fraction presented the highest concentrations for B and Mn. The litterfall was seasonal with summer and spring differing statistically from winter and the temperature variable explains the deposition pattern of the same.
\end{abstract}

Key-words: fertilization; sustainability; forest nutrition

\section{INTRODUCTION}

With the growth of the world population, coupled with the increased consumption of forest products, commercial tree plantations have been one way out of meeting these demands. The world area occupied by tree plantations grew by 5 million hectares between 2000 - 2010 (FAO, 2015). According to IBÁ (2016), in Brazil and the state of Rio Grande do Sul, this increase was verified, registering an increase of 60.7 and $58.1 \%$, respectively. In the state of Rio Grande do Sul, the largest expansion of the area was in the Pampa Biome, characterized by its sandy texture and low natural fertility (SUERTEGARAY and SILVA 2009).

Studies evaluating litterfall are important for understanding nutrient cycling, which provide support for the establishment of management techniques, fertilization and help in understanding interactions with the environment (SILVA et al., 2013). Although many studies evaluate litterfall and nutrient return in ecosystems (CORRÊA et al., 2013), few studies report micronutrients in forest formations (CORRÊA et al., 2016).

To understand nutrient cycling, it is necessary to evaluate the behavior of micronutrients and their relationship with macronutrient concentration in forest species (SOBRADO, 2014). Although required in small 
quantities compared to macronutrients (MORETTI et al., 2011), deficiency of the elements boron, copper, iron, manganese and zinc, decrease plant performance (SOBRADO, 2014), although greater concern is related excess, especially of B, Mn and Fe, which can lead to toxicity (LOPES et al., 2007), developing problems related to production, development and growth (GONÇALVES et al., 2004). The hypothesis of the present study is that the seasons determine litterfall and micronutrient concentration differ statistically according to the fraction evaluated.

The objective of the present study was to evaluate the seasonal yield of litterfall and its micronutrient content and the variation in different fractions in a stand of Eucalyptus dunnii from the sixth to the seventh year of age.

\section{MATERIALS AND METHODS}

\section{Area Description}

The experiment was conducted in a stand of Eucalyptus dunnii, with a spacing of $2.0 \mathrm{mx} 3.5 \mathrm{~m}$, from January to December 2015. The area is located in the municipality of Alegrete-RS, under the central geographic coordinates. of $29^{\circ} 47$ ' 10 'S and $55^{\circ} 17^{\prime} 30^{\prime \prime} \mathrm{O}$.

The climate of the region is of the humid sub-temperate Cfa type, which is characterized by constant precipitation throughout the year, the warmest month temperature above $22^{\circ} \mathrm{C}$ and the coldest month temperature above $3^{\circ} \mathrm{C}$. (ALVARES et al., 2014). Summers may have a dry period, with an average annual temperature of $18.6^{\circ} \mathrm{C}$ and an average annual precipitation of 1,747 mm (ALVARES et al., 2014). The species Eucalyptus dunnii is classified with average climatic aptitude for the region (FLORES et al., 2016).

Figure 1 shows the climatic diagram with the precipitation $(\mathrm{mm})$ and temperature $\left({ }^{\circ} \mathrm{C}\right)$ variables measured during the period, as well as the historical averages of ETP evapotranspiration (mm) according to Agritempo (2018).

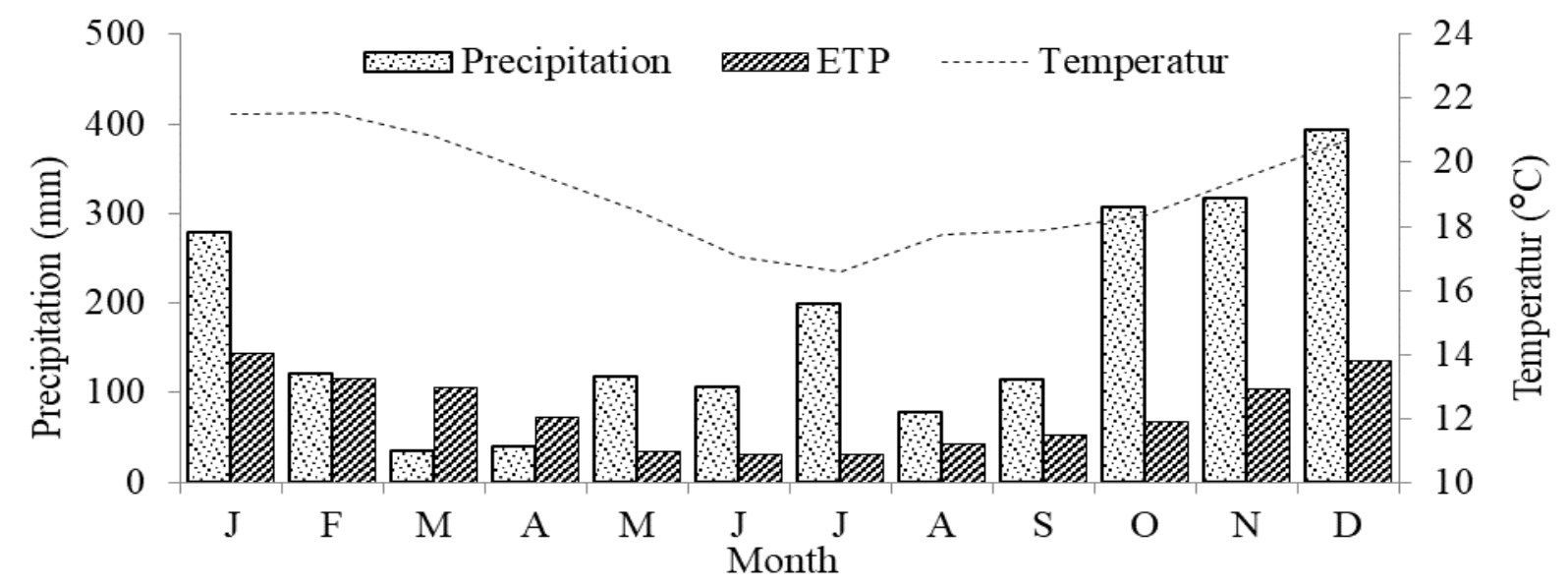

Figure 1. Climatic diagram of temperature $\left({ }^{\circ} \mathrm{C}\right)$, precipitation $(\mathrm{mm})$ and evapotranspiration ETP $(\mathrm{mm})$ in the region.

Figura 1. Diagrama climático de temperatura $\left({ }^{\circ} \mathrm{C}\right)$, precipitação $(\mathrm{mm})$ e evapotranspiração ETP $(\mathrm{mm})$ para a região. 
Table 1. Soil chemical and physical attributes on Eucalyptus dunnii stands in Alegrete RS, during the planting of the seedlings.

Tabela 1. Atributos químico-físicos do solo em povoamento de Eucalyptus dunnii em Alegrete-RS, por ocasião do plantio das mudas.

\begin{tabular}{|c|c|c|c|c|c|c|}
\hline \multirow{2}{*}{ Variable } & \multirow{2}{*}{ Unit } & \multicolumn{5}{|c|}{ Depth $(\mathrm{cm})$} \\
\hline & & $0-20$ & $20-40$ & $40-60$ & $60-80$ & $80-100$ \\
\hline MOS & \multirow{4}{*}{$\%$} & 1,0 & 0,9 & 0,8 & 0,8 & 0,7 \\
\hline Sand & & 78,0 & 77,0 & 72,0 & 69,0 & 64,0 \\
\hline Silt & & 7,0 & 6,0 & 7,0 & 8,0 & 10,0 \\
\hline Clay & & 15,0 & 17,0 & 21,0 & 23,0 & 26,0 \\
\hline $\mathrm{pH}$ & (1:2,5água) & 4,7 & 4,8 & 5,0 & 5,0 & 5,0 \\
\hline $\mathrm{Al}$ & \multirow{3}{*}{$\mathrm{cmol}_{\mathrm{c}} \mathrm{dm}^{-3}$} & 2,0 & 1,9 & 1,9 & 2,0 & 1,7 \\
\hline $\mathrm{Ca}$ & & 0,5 & 0,8 & 1,2 & 1,8 & 1,9 \\
\hline $\mathrm{Mg}$ & & 0,3 & 0,2 & 0,3 & 0,3 & 0,4 \\
\hline $\mathrm{P}$ & \multirow{2}{*}{$\mathrm{mg} \mathrm{dm}^{-3}$} & 1,9 & 1,6 & 1,5 & 1,5 & 1,5 \\
\hline $\mathrm{K}$ & & 20,3 & 12,0 & 9,7 & 8,3 & 8,3 \\
\hline $\mathrm{t}$ & \multirow{2}{*}{$\mathrm{cmol}_{\mathrm{c}} \mathrm{dm}^{-3}$} & 2,8 & 3,0 & 3,4 & 4,2 & 4,0 \\
\hline $\mathrm{T}$ & & 9,0 & 9,6 & 10,1 & 10,8 & 10,9 \\
\hline $\mathrm{V}$ & \multirow{2}{*}{$\%$} & 9,1 & 11,0 & 15,1 & 20,5 & 21,2 \\
\hline $\mathrm{m}$ & & 71,3 & 65,0 & 55,7 & 48,4 & 43,2 \\
\hline $\mathrm{S}$ & \multirow{4}{*}{$\mathrm{mg} \mathrm{dm^{-3 }}$} & 2,7 & 5,1 & 3,4 & 4,2 & 6,1 \\
\hline B & & 0,3 & 0,4 & 0,5 & 0,4 & 0,4 \\
\hline $\mathrm{Cu}$ & & 2,3 & 2,1 & 2,2 & 2,2 & 2,0 \\
\hline $\mathrm{Zn}$ & & 0,6 & 0,3 & 0,2 & 0,2 & 0,3 \\
\hline
\end{tabular}
CTC.

Table 1 shows the chemical and physical attributes of soil at 2 years of age (DICK et al., 2016). During planting, November 2008, the soil was subsoiled to $60 \mathrm{~cm}$ deep, with $300 \mathrm{~kg} \mathrm{ha}^{-1}$ of natural phosphate applied to the planting line. After 15 days, $140 \mathrm{~kg} \mathrm{ha}^{-1}$ of $\mathrm{N}-\mathrm{P} 2 \mathrm{O} 5-\mathrm{K} 2 \mathrm{O}$, formulation $06-30-06,+0.6 \%$ boron were incorporated into the soil. The second fertilizer addition was at 90 days after planting, where $140 \mathrm{~kg} \mathrm{ha}^{-1}$ of N $\mathrm{P} 2 \mathrm{O} 5$ - K2O, formulation $22-05-20,+0.2 \%$ boron $+0.4 \%$ zinc (a haul). The third fertilization was at 270 days, using $140 \mathrm{~kg} \mathrm{ha}^{-1}$ of $\mathrm{N}-\mathrm{P} 2 \mathrm{O} 5-\mathrm{K} 2 \mathrm{O}$, formulation $22-00-18,+1.0 \%$ sulfur $+0.3 \%$ boron.

\section{Litterfall collection and analysis}

The experiment had the demarcation of 4 plots of $20 \mathrm{~m} \times 21 \mathrm{~m}$, containing in each of them 4 litter traps with an area equal to $0.5 \mathrm{~m}^{2}$ and arranged in the positions: line, interline, diagonal and tree, totaling 16 . The thick branches (diameter greater than $0.5 \mathrm{~cm}$ ) were collected with 4 plots of $7 \mathrm{~m}^{2}$, based on medium diameter trees. The seasons (treatments) were as follows: summer (January, February and March), autumn (April, May and June), winter (July, August and September) and spring (October, November and December).

The collections were biweekly and the samples were separated into the fractions leaves, twigs, thick branches and miscellaneous (reproductive material, bark and fragments of plant tissue not identifiable). The litterfall was dried in a renovation oven and forced air circulation at $70{ }^{\circ} \mathrm{C}$ until reaching constant weight. They were then weighed on a $0.01 \mathrm{~g}$ precision scale for dry weight determination. The total amount of litterfall $\left(\mathrm{kg} \mathrm{ha}^{-}\right.$ $\left.{ }^{1}\right)$ per plot and season was estimated using Equation 1.

$$
\mathrm{PES}=\frac{(\Sigma \mathrm{PS}) \times 10000}{(\Sigma \mathrm{AC})}(1)
$$

Where: PES = seasonal litter production in $\mathrm{kg} \mathrm{ha}^{-1}$; PS = average litter yield of collectors in the season $(\mathrm{kg})$; $\sum \mathrm{AC}=$ sum of collector area in $\left(\mathrm{m}^{2}\right)$.

The monthly litter yield in $\mathrm{Mg} \mathrm{ha}^{-1}$ was calculated by dividing the total yield of the year by 12 months. After drying, each fraction was milled in a Wiley mill and chemically analyzed at the Forest Ecology Laboratory - UFSM.

For the determination of micronutrients B, Cu, Fe, Mn and Zn, the methodology of Tedesco et al., 1995 was followed. For $\mathrm{Cu}, \mathrm{Fe}, \mathrm{Mn}$ and $\mathrm{Zn}$ micronutrients, nitric-perchloric digestion ( $\mathrm{HNO} 3+\mathrm{HClO} 4)$ and extracts 
analyzed by atomic absorption spectrometry were used in Perkin Elmer, Analist 200 equipment. For boron extraction, digestion was performed drought and spectrophotometer analysis, with wavelength reading of 460 nm.

\section{Statistical analysis}

Data analysis was performed using IBM SPSS 20 software. The 4 plots were considered as repetition and the different seasons as treatments: summer (January, February and March), autumn (April, May and June), winter (July, August, and September) and spring (October, November, and December). After statistically significant difference was verified by applying the Tukey test at $5 \%$ probability of error.

In order to verify the influence of climatic variables on the litter deposition pattern, Pearson correlation was applied between the quantities of the different fractions and the climatic variables. Climatic data were obtained from the Alegrete-RS automatic station (AGRITEMPO 2018), about $30 \mathrm{~km}$ from the experimental area.

The variation of micronutrient concentrations were worked considering the seasons as independent variables (treatments). Secondly, the concentration variation in the different fractions of the litter was verified. In both 2 cases, a Tukey test at $5 \%$ probability of error was applied.

\section{RESULTS}

The total litterfall was $8.48 \mathrm{Mg} \mathrm{ha}^{-1}$, being the most representative leaf fraction (Table 2). The order of material deposited was as follows: leaves $>$ thick branches $>$ twigs $>$ miscellaneous, representing $59.3 ; 18.6 ; 11.1$ and $11 \%$, respectively. The comparison of averages between the seasons shows that there was a significant difference between the winter season and the spring and summer seasons, however, the summer, autumn and spring seasons did not differ statistically. (Figure 2).

Table 2. Litterfall in the different fractions, in Eucalyptus dunnii stand, from sixth to seventh year of age.

Tabela 2. Produção de serapilheira total nas diferentes frações, em povoamento de Eucalyptus dunnii, do sexto ao sétimo ano de idade.

\begin{tabular}{cccc}
\hline Fraction & $\left(\mathbf{M g ~ h a}^{-\mathbf{1}}\right)$ & $\mathbf{( \% )}$ & Monthly average $\left(\mathbf{M g ~ h a} \mathbf{-}^{\mathbf{1}}\right)$ \\
\hline Leaf & $5,17 \pm 0,23$ & 59,30 & 0,43 \\
Twigs & $0,92 \pm 0,05$ & 11,12 & 0,08 \\
Thick branches & $1,46 \pm 0,08$ & 18,59 & 0,12 \\
Miscellaneous & $0,92 \pm 0,06$ & 11,02 & 0,08 \\
\hline Total & $8,48 \pm 0,28$ & 100 & 0,71 \\
\hline
\end{tabular}

\pm Standard deviation in $\mathrm{Mg} \mathrm{ha}^{-1}$.

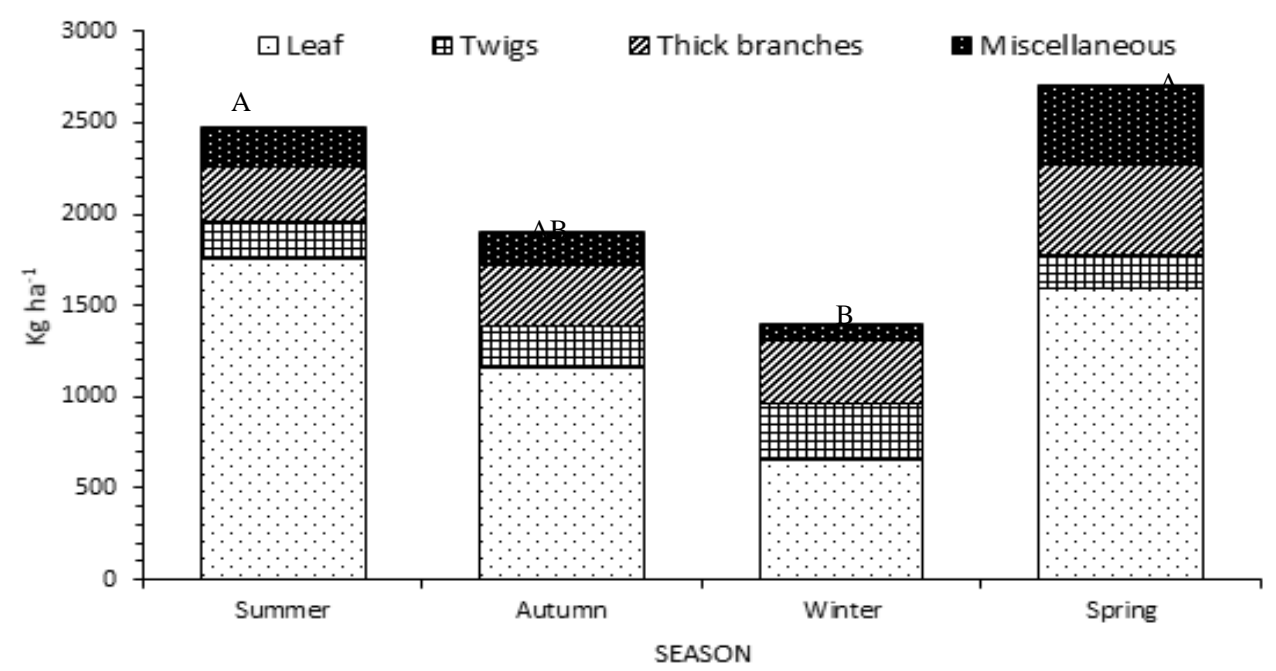

Figure 2. Seasonal litterfall in $\left(\mathrm{kg} \mathrm{ha}^{-1}\right)$ in the different fractions: leaf, twigs, thick branches and miscellaneous in Eucalyptus dunnii from sixth to seventh year of age.

Figura 2. Produção de serapilheira estacional (em kg ha ${ }^{-1}$ ) nas diferentes frações: folhas (F), galhos finos (GF), galhos grossos (GG) e miscelânea (M) em área de cultivo com Eucalyptus dunnii, do sexto ao sétimo ano de idade. 
Table 3. Average concentration of micronutrients in the different fractions of litterfall and annual seasons from Eucalyptus dunnii.

Tabela 3. Concentração média de micronutrientes nas diferentes frações da serapilheira e estações do ano em povoamento de Eucalyptus dunnii.

\begin{tabular}{|c|c|c|c|c|c|}
\hline Season & B & $\mathrm{Cu}$ & $\mathrm{Fe}$ & Mn & $\mathbf{Z n}$ \\
\hline Leaf & & & g kg & & \\
\hline Summer & $35,8 \mathrm{AB}$ & $\begin{array}{ll}4,7 \quad \mathrm{~B} \\
\end{array}$ & $129,0 \mathrm{~A}$ & $988,7 \mathrm{AB}$ & $7,7 \mathrm{~A}$ \\
\hline Autumn & $38,9 \mathrm{~A}$ & $5,2 \mathrm{AB}$ & 109,1 B & 851,4 B & 7,7 A \\
\hline Winter & $30,7 \quad$ B & $6,2 \mathrm{~A}$ & $127,2 \mathrm{~A}$ & 860,1 B & $8,6 \mathrm{~A}$ \\
\hline Spring & $33,5 \mathrm{AB}$ & $5,7 \mathrm{AB}$ & $137,8 \mathrm{~A}$ & $1062,4 \mathrm{~A}$ & $7,1 \mathrm{~A}$ \\
\hline Average & $34,7 \pm 6,4$ & $5,4 \pm 1,2$ & $125,8 \pm 18,8$ & $940,6 \pm 162,3$ & $7,8 \pm 1,9$ \\
\hline \multicolumn{6}{|l|}{ Twigs } \\
\hline Summer & $9,3 \mathrm{~A}$ & $8,3 \mathrm{AB}$ & $58,6 \mathrm{~A}$ & $415,6 \mathrm{~A}$ & $10,3 \mathrm{AB}$ \\
\hline Autumn & $12,9 \mathrm{~A}$ & $7,3 \mathrm{~B}$ & $64,4 \mathrm{~A}$ & 409,9 A & $7,8 \mathrm{~B}$ \\
\hline Winter & $12,3 \mathrm{~A}$ & $9,0 \mathrm{~A}$ & $75,9 \mathrm{~A}$ & $488,3 \mathrm{~A}$ & $13,2 \mathrm{~A}$ \\
\hline Spring & $12,1 \mathrm{~A}$ & $7,7 \mathrm{AB}$ & $82,0 \mathrm{~A}$ & $475,9 \mathrm{~A}$ & $11,5 \mathrm{~A}$ \\
\hline Average & $11,6 \pm 3,7$ & $8,0 \pm 1,5$ & $69,8 \pm 35,9$ & $444,7 \pm 108,7$ & $10,5 \pm 3,5$ \\
\hline \multicolumn{6}{|l|}{$\begin{array}{c}\text { Thick } \\
\text { branches }\end{array}$} \\
\hline Summer & $5,5 \mathrm{~B}$ & $4,6 \mathrm{~A}$ & $55,8 \mathrm{~B}$ & $432,0 \mathrm{~A}$ & $9,7 \mathrm{~A}$ \\
\hline Autumn & $9,4 \mathrm{~A}$ & $4,2 \mathrm{~A}$ & $58,6 \mathrm{~B}$ & $492,3 \mathrm{~A}$ & $6,8 \mathrm{~A}$ \\
\hline Winter & $8,6 \mathrm{~A}$ & $5,4 \mathrm{~A}$ & $121,9 \mathrm{~A}$ & $522,5 \mathrm{~A}$ & $8,5 \mathrm{~A}$ \\
\hline Spring & $9,3 \mathrm{~A}$ & $5,3 \mathrm{~A}$ & $54,8 \mathrm{~B}$ & $532,3 \mathrm{~A}$ & $10,5 \mathrm{~A}$ \\
\hline Average & $8,2 \pm 2,5$ & $4,9 \pm 1,5$ & $71,2 \pm 65,4$ & $495,0 \pm 120,1$ & $8,9 \pm 3,7$ \\
\hline \multicolumn{6}{|c|}{ Miscellaneous } \\
\hline Summer & $16,1 \mathrm{~B}$ & $3,7 \mathrm{BC}$ & $144,1 \mathrm{~B}$ & $405,0 \mathrm{~B}$ & $4,5 \mathrm{~B}$ \\
\hline Autumn & $21,2 \mathrm{~A}$ & $3,6 \mathrm{C}$ & 206,1 B & $388,6 \mathrm{~B}$ & $6,4 \mathrm{AB}$ \\
\hline Winter & $19,9 \mathrm{AB}$ & $6,2 \mathrm{~A}$ & $561,1 \mathrm{~A}$ & $509,5 \mathrm{~A}$ & $10,2 \mathrm{~A}$ \\
\hline Spring & $16,5 \mathrm{~B}$ & 5,9 AB & $282,1 \mathrm{AB}$ & $528,8 \mathrm{~A}$ & $10,0 \mathrm{~A}$ \\
\hline Average & $18,4 \pm 4,3$ & $4,8 \pm 2,3$ & $292,8 \pm 322,6$ & $456,9 \pm 91,2$ & $7,7 \pm 4,8$ \\
\hline
\end{tabular}

Regarding the micronutrient concentrations in the different fractions of the litter, we can observe that B and $\mathrm{Mn}$ presented higher contents $(\mathrm{p} \leq 0,05)$ in the leaves component, $\mathrm{Cu}$ in the thin branches and $\mathrm{Fe}$ in the miscellaneous. The $\mathrm{Zn}$ element did not differ statistically $(\mathrm{p} \leq 0.05)$ between the different fractions (Figure 3 ). The micronutrient concentration order in the different fractions was equal for all elements $(\mathrm{Mn}>\mathrm{Fe}>\mathrm{B}>\mathrm{Zn}>$ $\mathrm{Cu})$ except for thick branches $(\mathrm{Mn}>\mathrm{Fe}>\mathrm{Zn}>\mathrm{B}>\mathrm{Cu})$. 


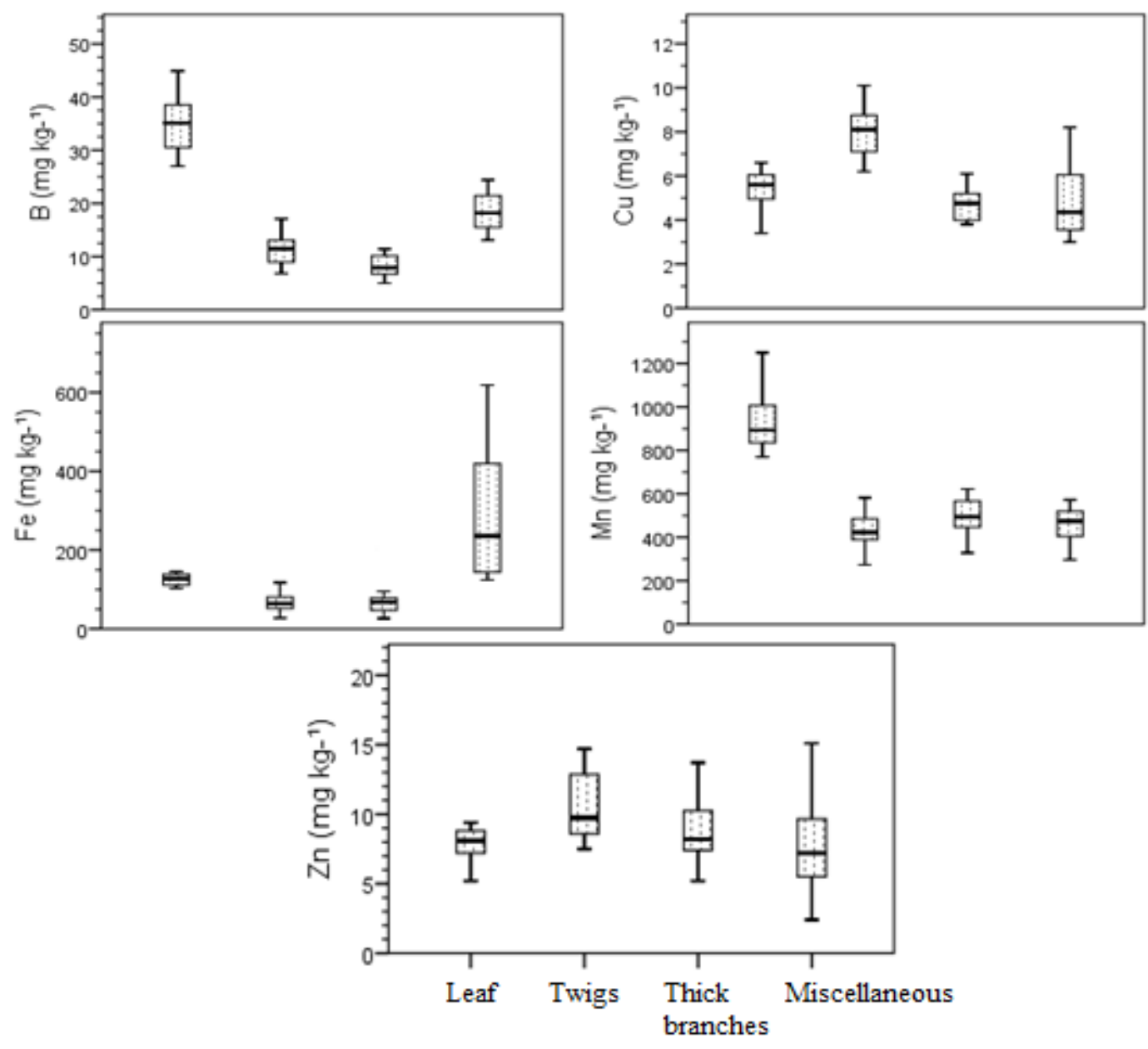

Fraction

Figure 3. Average concentration of micronutrients in the litterfall fractions leaf, twigs, tick branches and miscellaneous in Eucalyptus dunnii stand.

Figura 3. Concentração média de micronutrientes da serapilheira nas frações folha, galho fino, galho grosso e miscelânea em povoamento de Eucalyptus dunnii.

Nutrient input via litter followed the following order: $\mathrm{Mn}>\mathrm{Fe}>\mathrm{B}>\mathrm{Zn}>\mathrm{Cu}$, totaling $8.04 \mathrm{~kg} \mathrm{ha}^{-1}$ (Table 4). The total quantities of $\mathrm{Mn}$ corresponded to $82,8 \%$ of the total micronutrients. About $75 \%$ of the micronutrients were in the leaf fraction.

Table 4. Annual return of micronutrients on the litterfall fractions in Eucalyptus dunnii stands.

Tabela 4. Aporte de micronutrientes anual nas frações da serapilheira em povoamento de Eucalyptus dunnii.

\begin{tabular}{|c|c|c|c|c|c|c|}
\hline \multirow{2}{*}{ Fraction } & B & $\mathbf{C u}$ & $\mathbf{F e}$ & Mn & $\mathbf{Z n}$ & \multirow{2}{*}{ Total } \\
\hline & \multicolumn{5}{|c|}{ g ha $^{-1}$} & \\
\hline Leaf & $\begin{array}{c}179 \\
(2,23) *\end{array}$ & $\begin{array}{c}28 \\
(0,35)\end{array}$ & $\begin{array}{c}672 \\
(8,36)\end{array}$ & $\begin{array}{c}5095 \\
(63,36)\end{array}$ & $\begin{array}{c}39 \\
(0,49)\end{array}$ & $\begin{array}{c}6013 \\
(74,78)\end{array}$ \\
\hline Twigs & $\begin{array}{c}11 \\
(0,13)\end{array}$ & $\begin{array}{c}7 \\
(0,09)\end{array}$ & $\begin{array}{c}64 \\
(0,80)\end{array}$ & $\begin{array}{c}419 \\
(5,21)\end{array}$ & $\begin{array}{c}10 \\
(0,13)\end{array}$ & $\begin{array}{c}511 \\
(6,35)\end{array}$ \\
\hline Thick branches & $\begin{array}{c}12 \\
(0,15)\end{array}$ & $\begin{array}{c}6 \\
(0,08)\end{array}$ & $\begin{array}{c}114 \\
(1,42)\end{array}$ & $\begin{array}{c}721 \\
(8,97)\end{array}$ & $\begin{array}{c}12 \\
(0,15)\end{array}$ & $\begin{array}{c}867 \\
(10,78)\end{array}$ \\
\hline Miscellaneous & $\begin{array}{c}16 \\
(0,20)\end{array}$ & $\begin{array}{c}4 \\
(0,05)\end{array}$ & $\begin{array}{c}201 \\
(2,49)\end{array}$ & $\begin{array}{c}423 \\
(5,26)\end{array}$ & $\begin{array}{c}7 \\
(0,08)\end{array}$ & $\begin{array}{c}650 \\
(8,09)\end{array}$ \\
\hline Total & $\begin{array}{c}218 \\
(2,71)\end{array}$ & $\begin{array}{c}46 \\
(0,57)\end{array}$ & $\begin{array}{c}1051 \\
(13,08)\end{array}$ & $\begin{array}{c}6658 \\
(82,80)\end{array}$ & $\begin{array}{c}68 \\
(0,84)\end{array}$ & $\begin{array}{c}8041 \\
(100,00)\end{array}$ \\
\hline
\end{tabular}

* Values in parentheses refer to percentages of micronutrients in each fraction. 


\section{DISCUSSION}

Viera et al. (2014) evaluated litterfall in a hybrid stand Eucalyptus urophylla $\mathrm{x}$ Eucalyptus globulus and found an average annual production of $7.54 \mathrm{Mg} \mathrm{ha}^{-1}$, from 5.5 to 9.5 years old. The order of deposition of the fractions was as follows: leaves> twigs> miscellaneous> thick branches, representing 66.9; $14.7 ; 10.5$ and 7.9\%, respectively.

Evaluating litter deposition in a 1.5-year-old stand of Eucalyptus dunnii, Corrêa et al. (2016) found the following order of material accumulation: leaves> miscellaneous> thick branches, corresponding to 93,6 and $1 \%$, respectively. Ludvichak et al. (2016), with the same species, but from the 5th to the 6th grade, found a litter production of $6.99 \mathrm{Mg} \mathrm{ha}^{-1}$ in the following order: leaves> twigs> thick branches> miscellaneous, corresponding to $61.6 ; 17.3 ; 13.8$ and $7.2 \%$, respectively. The percentage of participation of the thick branch component in the present study is due to the maturity of the stand, because as it ages, the branches inserted in the lower thirds are deposited due to shading, reducing the percentage of the other fractions.

Several studies have found that the leaves represent the major component, with percentages ranging from 60 to $93 \%$, with only the intrinsic variation being the maturity, the species and the place where the settlement is established (LUDVICHAK et al. 2016; CORRÊA et al 2016).

According to Viera et al. (2014), increasing temperature may accelerate the rate of transpiration, which strategically makes there is a greater senescence of mature leaves. Other authors also report deposition peaks in autumn or winter, mainly caused by falling temperatures (CORRÊA et al. 2016), a period marked by water scarcity or coinciding with the fall of mature leaves when new leaves are emitted, due to the most abundant radiation periods (BIANCHIN et al. 2016). Table 5 shows the correlations between litterfall and climate variables. It is observed that the variables temperature (minimum, average and maximum), evapotranspiration and solar radiation, are responsible for explaining the deposition pattern, with correlations that reach $82 \%$ and a level of error probability of less than $1 \%$.

Table 5- Pearson correlation between climatic variables and deposition of leaf, twig, thick branches, miscellaneous and litterfall for the period studied.

Tabela 5- Correlação de Pearson entre as variáveis climáticas e a deposição de folhas, galhos finos, galhos grossos, miscelânea e serapilheira total para o período estudado.

\begin{tabular}{lccccc}
\hline Variable & Litterfall & Leaf & Twigs & Thick branches & Miscellaneous \\
\hline Precipitation $(\mathrm{mm})$ & $\mathrm{ns}$ & $\mathrm{ns}$ & $\mathrm{ns}$ & $\mathrm{ns}$ & $\mathrm{ns}$ \\
Minimum temperature $\left({ }^{\circ} \mathrm{C}\right)$ & $0,80^{* *}$ & $0,82^{* *}$ & $\mathrm{~ns}$ & $\mathrm{~ns}$ & $\mathrm{~ns}$ \\
Average temperature $\left({ }^{\circ} \mathrm{C}\right)$ & $0,79^{* *}$ & $0,82^{* *}$ & $\mathrm{~ns}$ & $\mathrm{~ns}$ & $\mathrm{~ns}$ \\
Maximum temperature $\left({ }^{\circ} \mathrm{C}\right)$ & $0,78^{* *}$ & $0,80^{* *}$ & $\mathrm{~ns}$ & $\mathrm{~ns}$ & $\mathrm{~ns}$ \\
No rain (days) & $\mathrm{ns}$ & $\mathrm{ns}$ & $\mathrm{ns}$ & $\mathrm{ns}$ & $\mathrm{ns}$ \\
Minimum humidity $(\%)$ & $\mathrm{ns}$ & $\mathrm{ns}$ & $\mathrm{ns}$ & $\mathrm{ns}$ & $\mathrm{ns}$ \\
Maximum humidity $(\%)$ & $\mathrm{ns}$ & $\mathrm{ns}$ & $0,68^{*}$ & $\mathrm{~ns}$ & $\mathrm{~ns}$ \\
evapotranspiration $(\mathrm{mm})$ & $0,76^{* *}$ & $0,79^{* *}$ & $\mathrm{~ns}$ & $\mathrm{~ns}$ & $\mathrm{~ns}$ \\
Solar radiation $\left(\mathrm{MJ} / \mathrm{m}^{2} / \mathrm{day}\right)$ & $0,65^{*}$ & $0,67^{*}$ & $\mathrm{~ns}$ & $\mathrm{~ns}$ & $\mathrm{~ns}$ \\
Wind $(\mathrm{m} / \mathrm{s})$ & $\mathrm{ns}$ & $\mathrm{Ns}$ & $\mathrm{ns}$ & $\mathrm{ns}$ & $\mathrm{ns}$ \\
\hline
\end{tabular}

Significant: * $(\mathrm{p} \leq 0,05) ; * *(\mathrm{p} \leq 0,01)$; ns: not significant. Source: Agritempo (2018).

\section{Nutrients in litterfall}

Viera et al. (2014), evaluating litterfall and nutrients in a 5.5-year-old Eucalyptus urophylla x E. globulus hybrid, also found higher B and $\mathrm{Mn}$ contents in leaves and $\mathrm{Fe}$ in miscellany, however, $\mathrm{Cu}$ and $\mathrm{Zn}$ did not differed between fractions, for the authors, the order of concentration was as follows: $\mathrm{Mn}>\mathrm{Fe}>\mathrm{B}>\mathrm{Zn}>\mathrm{Cu}$. Ludvichak et al. (2016), evaluating micronutrient contents in Eucalyptus dunnii litterfall in the same area, but at 5 years of age, also observed that $\mathrm{Cu}$ and $\mathrm{Zn}$ did not differ statistically between fractions. 
Generally, micronutrient levels tend to increase with the age of the stand. Gonçalves et al. (2004) showed that in Eucalyptus grandis, the average micronutrient translocation from senescent leaves to green leaves was only 18; 79; 37; 28 and 14\% for B, Zn, Cu, Fe and Mn, respectively. The low concentrations observed for $\mathrm{Zn}$ and $\mathrm{Cu}$ are related to their greater plant mobility (DECHEN; NACHTIGAL, 2006). In the present study, there was also a significant difference of $\mathrm{B}$ between the autumn and winter seasons, $\mathrm{Cu}$ in the winter and summer seasons, and Fe between the autumn season compared to the others. Equal finding was obtained by Corrêa et al. (2016) studying the same specie at 1.5 years old.

Pearson correlation showed antagonism between leaf $\mathrm{Mn}$ and $\mathrm{Zn}$ concentrations, with a correlation of $70.7 \%$ a $(\mathrm{p} \leq 0.05)$. These patterns were also identified by Corrêa et al. (2016) and Dechen and Nachtigal (2006) in their studies.

For the present study, the mean Mn content in the leaf fraction was $941 \mathrm{mg} \mathrm{kg}^{-1}$. Corrêa et al. (2016) studying the species Eucalyptus dunnii found $1854 \mathrm{mg} \mathrm{kg}^{-1}$ at 1.5 years. Ludvichak et al. (2016) also with the same species found $1253 \mathrm{mg} \mathrm{kg}^{-1}$ at 5 years. According to Jiménez and Navarro (2015), this decreasing trend as the stand ages has also been observed in a Pinus plantation, 5 years after thinning in semiarid climate. For the authors, the decline in Mn concentration in the needles is due to the maturity of the stand where the element ends up being partially translocated. According to Motta et al. (2007), the availability of Mn increases as $\mathrm{pH}$ decreases in the soil. In the present study, soil $\mathrm{pH}$ was classified as acid.

Regarding the concentration of $\mathrm{Mn}$ in the thick branch fraction, the element presented inverse behavior as seen in the leaf fraction. Corrêa et al. (2016) at 1.5 years reported $317 \mathrm{mg} \mathrm{kg}^{-1}$, Ludvichak et al. (2016) at 5 years found $472 \mathrm{mg} \mathrm{kg}^{-1}$ and in the present study at 7 years was $721 \mathrm{mg} \mathrm{kg}^{-1}$. One of the functions of Mn is the participation in the electron transport of photosynthesis, which justifies its lower contents in thick branches (PRADO, 2008).

The rate of nutrient release in Eucalyptus dunnii leaves was studied by Momolli et al. 2018. Using the litterbag technique, the authors found that after 12 months, 64 and $75 \%$ of $\mathrm{Mn}$ and B had been released from the leaves. These percentages converted to the present study would represent $3.4 \mathrm{~kg} \mathrm{ha}^{-1}$ of $\mathrm{Mn}+\mathrm{B}$, representing an important source of micronutrients.

\section{CONCLUSIONS}

- Litter deposition is seasonal and the climate variable temperature regulating the deposition pattern in Eucalyptus dunnii stand in southern Brazil.

- Leaf fraction represented $60 \%$ of mass and $75 \%$ of micronutrients.

- The transfer order was: $\mathrm{Mn}>\mathrm{Fe}>\mathrm{B}>\mathrm{Zn}>\mathrm{Cu}$, totaling $8.04 \mathrm{~kg} \mathrm{ha}^{-1}$, of which $83 \%$ is $\mathrm{Mn}$.

- Considering the leaf fraction decomposition rate presented by Momolli et al. 2018, $3.4 \mathrm{~kg} \mathrm{ha}^{-1}$ of $\mathrm{Mn}^{-}$ and $\mathrm{B}$ would be released from leaves 12 months after deposition.

\section{REFERENCES}

AGRITEMPO. Dados meteorológicos - Alegrete. Campinas, 2018. Disponível em: <http://www.agritempo.gov.br>. Acesso em: 01 dez. 2018.

ALVARES, C.A.; STAPE, J.L.; SENTELHAS, P.C.; GONÇALVES, J.L.M.; SPAROVEK, G. Köppen's climate classification map for Brazil. Meteorologische Zeitschrift, v. 22, n. 6, p. 711-728, 2014.

BIANCHIN, J.E.; MARQUES, R.; BRITEZ, R.M.; CAPRETZ, R. L. Deposição de Fitomassa em formações secundárias na Floresta Atlântica do Paraná. Floresta e Ambiente, v. 23, n. 4, p. 524-533, 2016.

CORRÊA, R.S.; SCHUMACHER, M.V.; MOMOLLI, D.R. Deposição de serapilheira e macronutrientes em povoamento de Eucalyptus dunnii Maiden sobre pastagem natural degradada no Bioma Pampa. Scientia Forestalis, v. 41, n. 97, p. 65-74, 2013. 
CORRÊA, R.S.; SCHUMACHER, M.V.; MOMOLLI, D.R. Deposição de serapilheira e micronutrientes ao longo das estacoes do ano em um plantio de eucalipto estabelecido sobre pastagem natural degradada no bioma pampa. Scientia Forestalis, v. 44, p. 435 - 442, 2016.

DECHEN, A. R.; NACHTIGALL, G. R. Micronutrientes. In: FERNANDES, M. S. (Ed.) Nutrição mineral de plantas. Viçosa: SBCS, 2006. p. 327-354.

DICK, G.; SCHUMACHER, M.V.; MOMOLLI, D.R. Caracterização da fertilidade do solo em um povoamento de Eucalyptus dunnii Maiden no bioma Pampa do Rio Grande do Sul. Ecologia e Nutrição Florestal, Santa Maria - RS, v.4, n.3, p.68-77, 2016.

FAO. Global Forest Resources Assessment 2015: Main Report. FAO Forestry Paper 253. Food and agriculture organization of the United Nations, Rome, Italy.

FLORES, T.B.; ALVARES, C.A.; SOUZA, V.C.; STAPE, J.L. Eucalyptus no Brasil: zoneamento climático e guia para identificação. Piracicaba: IPEF. 2016, 448p.

GONÇALVES, J.L.M.; STAPE, J.L.; BENEDETTI, V.; FASSEL, V.A.G.; GAVA J.L. An evaluation of minimun and intensive soil preparation regarding fertility and tree nutrition. In: Forest Nutrition and Fertilization. Piracicaba: IPEF, 2004. P. 13-64.

IBÁ - Indústria Brasileira de Árvores. 2016. Relatório anual 2016: ano base 2015. 80p.

JIMÉNEZ, M.N.; NAVARRO, F.B. Monthly foliar-nutrient pattern in a semiarid Aleppo pine plantation five years after thinning. Forest Ecology and Management. v. 343, n. 1, p. 63-72, 2015.

LOPES, J.L.W.; GUERRINI, I.A.; SAAD, J.C.C.; SILVA, M.R. Nutrição mineral de mudas de eucalipto produzidas sob diferentes lâminas de irrigação e substratos. Revista Brasileira de Ciência do Solo. v. 31, n. 1, p. 713-722, 2007.

LUDVICHAK, A.A.; SCHUMACHER, M.V.; DICK, G.; MOMOLLI, D.R.; SOUZA, H.P.; GUIMARÃES, C.C. Devolução de nutrientes através da serapilheira produzida em um povoamento de Eucalyptus dunnii maiden em solo arenoso. Revista Árvore. v. 40, n.6, p. 1051-1058, 2016.

MOMOLLI, D.R.; SCHUMACHER, M.V.; DICK, G.; VIERA, M.; SOUZA, H.P. Decomposição da serapilheira foliar e liberação de nutrientes em Eucalyptus dunnii no Bioma Pampa. Scientia Forestalis, v. 46, n. 118, p. 199-208, 2018.

MORETTI, B. S.; FURTINI NETO, A. E.; PINTO, S. I. C.; FURTINI, I. V.; MAGAlhãeS, C. A. S. Growth and mineral nutrition in seedlings of Australian cedar (Toona ciliata) subjected to nutrient deprivation, Cerne, v. 17, n. 4, p. 453-463, 2011.

MOTTA, A.C.V.; SERRAT, B.M.; REISSMANN, C.B.; DIONÍSIO, J.A. Micronutrientes na rocha no solo e na planta. Curitiba, 1ed. 2007, 246p.

PRADO, R.M. Nutrição de plantas. São Paulo: Editora UNESP. 2008, 407p.

SBCS-CQFS - Sociedade Brasileira de Ciência do Solo-Comissão de Química e Fertilidade do Solo - RS/SC. Manual de calagem e adubação para os Estados do Rio Grande do Sul e de Santa Catarina. $11^{\mathrm{a}}$ ed. Solo Núcleo Regional Sul. Porto Alegre. 2016, 376 p.

SILVA, P.H.M.; POGGIANI, F.; LIBARDI, P.L.; GONCALVES, A.N. Fertilizer management of eucalypt plantations on Sandy soil in Brazil: Initial growth and nutrient cycling. Forest Ecology and Management, v. 301, n. 1, p. 67-78. 2013.

SOBRADO, M.A. Relationship between leaf micro- and macro-nutrients in top canopy trees in a mixed forest in the upper Rio Negro in the Amazon region. American Journal of Plant Sciences, v. 5, n.1, p.1423 - 1431 , 2014.

FLORESTA, Curitiba, PR, v. 49, n. 4, p. 641 - 650 , out/dez 2019

Momolli, D. R. et.al.

ISSN eletrônico 1982-4688

DOI: $10.5380 /$ rf.v49 i4.56727 
SUERTEGARAY, D.M.A.; SILVA, L.A.P. Tchê Pampa: histórias da natureza gaúcha. In: PILAR, V.P. et al. Campos sulinos: conservação e uso sustentável da biodiversidade. 2009. Brasília: MMA, 1:42-59.

TEDESCO, M.J.; GINELLO, C.; BISSANI, C.A.; BOHNEN, H.; VOLKWEISS, S.J. Análise de solo, plantas e outros materiais. $2^{a}$.ed. Porto Alegre: Universidade Federal do Rio Grande do Sul; 1995. 174p.

VIERA, M.; SCHUMACHER, M.V.; ARAÚJO, E.F.; CORRÊA, R.S.; CALDEIRA, M.V.W. Deposição de serapilheira e nutrientes em plantio de Eucalyptus urophylla $\times$ Eucalyptus globulus. Floresta e Ambiente, v. 21, n. 3, p. 327-338, 2014. 